\title{
ERRATUM
}

\section{Erratum to: The closure operator and flats of $\Gamma$-extension matroids}

\author{
Morteza Kazemzade · Habib Azanchiler • Vahid Ghorbani
}

Published online: 20 August 2021

(C) The Indian National Science Academy 2021

Correction to: Indian J Pure Appl Mathe (2021)

https://doi.org/10.1007/s13226-021-00161-1

In this article the author name Habib Azanchiler was incorrectly written as Habid Azanchiler.

No other changes to the article have been made.

The original articles can be found online at https://doi.org/10.1007/s13226-021-00161-1 and https://doi.org/10.1007/s13226021-00161-1.

The online version of the original article can be found under 10.1007/s13226-021-00161-1.

M. Kazemzade $(\square) \cdot$ H. Azanchiler · V. Ghorbani

Department of Mathematics, Urmia University, Urmia, Iran

E-mail: mo.kazemzade@urmia.ac.ir

H. Azanchiler

E-mail: h.azanchiler@urmia.ac.ir

V. Ghorbani

E-mail: v.ghorbani@urmia.ac.ir 